\title{
Marketing Mix in the Market of Agricultural Machinery: Problems and Prospects
}

Irina A. Morozova

Professor of the Department of World economy and Economic theory, Volgograd State Technical University, Volgograd, Russia, Krasnoznamenskaya st., 8-71, Volgograd, Russia, 400005

Tatiana N. Litvinova

Senior lecturer of the Department of Management, Volgograd State Agrarian University, Volgograd, Russia

Ekaterina A. Rodina

Moscow Institute of State and Corporate Governance, Moscow, Russia rodina.ekaterina@gmail.com

\section{Nikolai Y. Prosvirkin}

Associate Professor of the Department of Management, Samara State Aerospace University, Samara, Russia nik-prosvirkin@yandex.ru

\section{Doi:10.5901/mjss.2015.v6n3s6p19}

\section{Abstract}

The authors analyze the dynamics of change of the basic parameters of the market of agricultural machinery in 2013, in \% to 2012 and determine the structure of the market of agricultural machinery by origin in 2011-2014. Among the problems of the Russian market of agricultural machinery authors mark out a sharp drop of agricultural production; insufficient level of solvency of farmers; excessively high load of ploughland per a tractor; rapid promotion of imported machinery and equipment to the national market; insufficient level of maintenance and servicing especially of consumers of imported used machinery. In the results of conducting of the research the authors come to a conclusion that nowadays marketing environment develops and changes so rapidly that attempts to look at, to describe some static picture, to make a mold of the market leads, rather, to misinformation than determination. In order to determine this sensitivity to changes in time such a definition as "duration of marketing" is introduced. During the recent years, duration of marketing was too big. The market is changing so rapidly that any marketing research is late. Invention of new methods of marketing research is necessary. Right up to such methods, that simultaneously with introducing of a new product a system of on-line marketing measurement would be created. Thereby, market environment is developing so rapidly that any marketing research is late. That is why it is necessary to constantly analyze marketing mix in the market of agricultural machinery, to detect its problems and prospects in order to maintain the necessary level of development of this market.

Keywords: marketing mix, prospects, problems, the market of agricultural machinery.

\section{Introduction}

The market of agricultural machinery is one of the priority and strategic sectors of the economy of any country including Russia, as it provides production of equipment for farming, which the national food security depends on. Under the conditions of market economy there are market mechanisms in the given market, and especially important becomes marketing as a tool to provide competitiveness of enterprises in the given market.

Agriculture in the context of the global food crisis is an important factor of economic growth. Nowadays there are a small number of countries in the world which are able to increase food production. These countries include Russia, which possess a unique potential in the agricultural sector. Nowadays Russia is an important player in the market of food, producing about $10.0 \%$ of the world's output of grain. Achievement of high indicators within agricultural production should be based on the contemporary technical support of AIC. 


\section{Subject Area}

Subject area of research is the Russian market of agricultural machinery.

\section{Methods and Methodology}

The volume of supply in the Russian market of agricultural machinery in 2013 decreased by $2 \%$ compared with 2012. The question remains open why farmers stop buying agricultural machinery, whether falling would continue in 2014-2015 and why state program of subsidizing agricultural producers appeared to be ineffective.

Agricultural Machinery Market in 2013 did not meet the expectations: after growth in 2011-2012, the volume of supply decreased by $2 \%$ in natural terms. The outgoing year of 2014 is also not encouraging: by the results of 2014, according to our estimates, the market 'will go' into negative by as much as $12 \%$ compared with the previous year (in natural terms).

At the same time the Russian market of agricultural machinery 'dipped' in 2012 at the expense of domestic production (-5\% in 2011), while imports increased by $5 \%$ (in real terms).

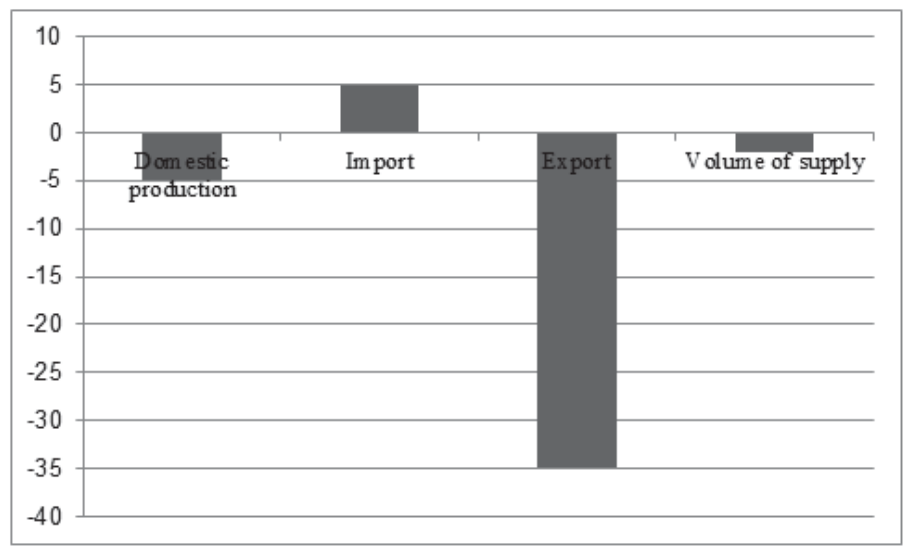

Figure 1. Increase / decrease of the basic parameters of the market of agricultural machinery in 2013 , in $\%$ to 2012 , in natural terms

According to the experts we surveyed, the factors of reduce of the volume of supply in 2012-2013 were, first, suspension of the Ministry of Agriculture to subsidize part of the discount rate of loans for purchasing agricultural machinery; secondly, reduce of farmers' incomes; thirdly, completion of re-equipment of farms (Cai \& Wang 2012).

Among other things, the state support of agricultural producers has changed. Earlier, agricultural enterprises had an opportunity to buy fuel and lubricants and fertilizers on preferential terms at the account of subsidizing loan rates by the state. Now the state aid will be 'targetedly' offered only to efficient farmers. Per hectare subsidies will be provided depending on the area of arable lands, production volumes and bioclimatic potential of the region. In addition, according to the view of farmers, the size of the subsidies per 1 hectare of arable land is significantly lower than in the developed countries.

Import deliveries rose against the background of decrease of domestic production. The reasons, in our mind, lie in the following: on the one hand, almost $90 \%$ of agricultural machinery in Russia is purchased on a lease or loan, on the other hand - farmers have to cut price costs of products and to use more efficient equipment. Obviously, under such conditions, the choice falls on imported machinery (primarily, this concerns trailed and mounted agricultural machinery).

Thus, the share of imported agricultural machinery constituted $20.5 \%$ in 2013 in natural terms, and by the results of January-September 2014 increased up to 32\% (Laping, 2013). 


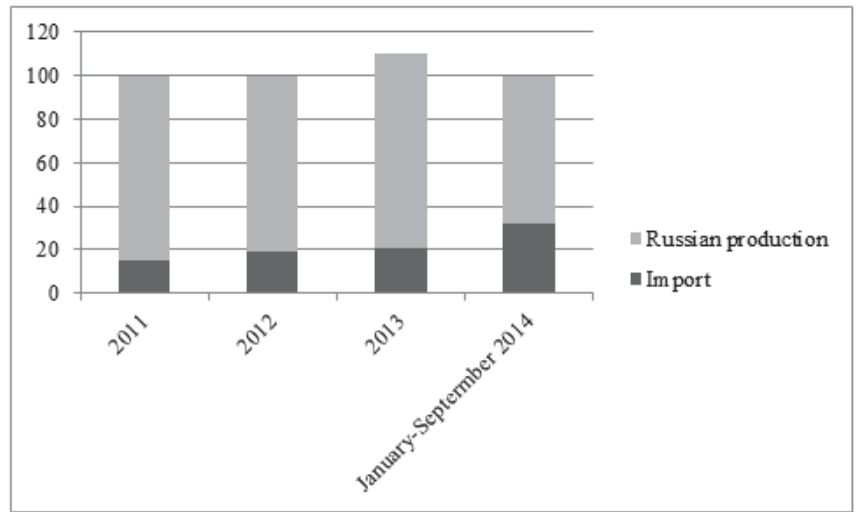

Figure 2. Structure of the market of agricultural machinery by origin, in natural terms in 2011-2014.

The second reason lies in the structure of import arrivals. According to the marketing research, prepared by I-Marketing, more than half of imports is accounted for tractors, with almost $50 \%$ of total imports accounted for wheeled tractors of Minsk Tractor Plant 'Belarus' (excluding the machinery kits delivered to Russia). It should be noted that the supplies of tractors and machinery kits of MTZ to Russia increased in 2013 by 3\% compared with 2012.

By the results of January-September 2014 the import supplies of agricultural machinery to Russia increased by $20 \%$ compared to the same period of 2013. The most significant increase is observed in the segment of combines (+ $68 \%$ ) and tractors (+ 29\%), but the supplies of other farm machinery decreased by $7 \%$.

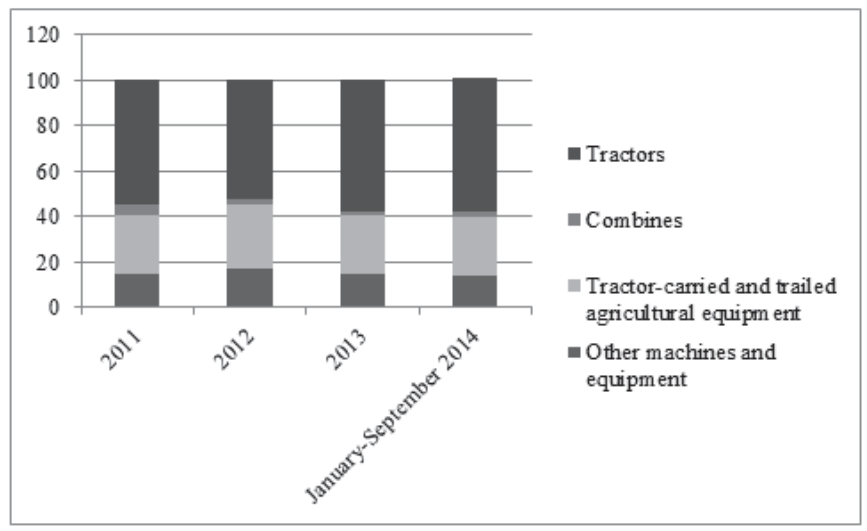

Figure 3. Increase / decrease of import supplies of agricultural machinery by types in January-September 2014 , in \% to the same period of 2013 , in natural terms

In order to support domestic manufacturers of agricultural machinery in 2013 a federal program to subsidize purchasing of agricultural machinery, calculated up to 2020, was launched. According to the terms of the program, manufacturers provide agricultural enterprises with $15 \%$ discount for manufactured machinery, and the state subsidizes these costs.

There is interest in the program, however, rush, according to the manufacturers, it is not observed. The program appeared to to be ineffective for several reasons. First, as we have noted, $90 \%$ of equipment is purchased on a lease and a loan. Secondly, the mechanism of the program is not fully debugged, which creates certain difficulties while its realization. Third, the regions face difficulties with getting and servicing loans.

Note that the first three months of the program the amount of the granted discounts constituted $225 \mathrm{mn}$ rub., which is about $10 \%$ of the total program budget for 2013 (2.3 bn rub.).

By the way, this is the second measure of the state support of domestic manufacturers of agricultural machinery in 2013. In the beginning of the year, the Eurasian Economic Commission (EEC) introduced protective duties on imports of combine harvesters and their modules in the countries of the Customs Union.

This measure will be maintained until March 2016, and the size of the duty constitutes $26.7 \%$ nowadays. What is awaiting the Russian market of agricultural machinery in 2013-2014? According to our estimates, in 2013 the volume of 
supply will decrease by 12-13\% in comparison with 2012 (Laping, 2013). Regarding 2014, it is early to make any conclusions due to macroeconomic uncertainty. According to our estimates, the vector of development would take shape under influence of positive and negative factors.

Negative factors in the medium-term prospect will be the following:

- stagnation of the Russian economy (growth rate will constitute 0.5-1.8\% in 2014-2015);

- slowing of development of the processing manufactures (growth rate will constitute 2\% in 2014-2015);

- a significant level of credit and overdue credit indebtedness of farms.

Among the positive factors it is possible to mark out:

- necessity of renewal of the fleet of agricultural machinery;

- support of farmers within the frameworks of the State program of development of agricultural and regulation of agricultural products, raw materials and food for 2013-2020;

- federal program of subsidizing manufacturers of agricultural machinery with funding of 2.3 billion rubles;

- regional sub-program of purchasing agricultural equipment.

As it can be seen, development of the market of agricultural machinery almost entirely depends on the state support measures. It is not clear yet whether the state will be able to fund the claimed programs in full.

Nevertheless, the interest in the Russian market from the side of foreign players does not weaken. Thus, until 2015 the existing farmers in Russia can be joined by other 3-4 plants.

At the moment, assembly manufacture in Russia is carried out by Deere\&Company (John Deere Domodedovo and John Deere Orenburg), AMAZONE (JSC 'Eurotechnica'), Lemken (LLC 'Lemken-Rus'), Horsch (LLC 'Horsh Rus'), Kverneland (LLC 'Kverneland Group Manufacturing Lipetsk'), CNH (LLC 'CNH-KAMAZ Industry'), Claas (LLC 'Klaas').

\section{Results}

Among the problems of the Russian market of agricultural machinery first of all one should mark out the following:

- sharp drop of production of agricultural machinery;

- insufficient level of solvency of farmers;

- $\quad$ excessively high load of plough land per tractor;

- $\quad$ rapid promotion of imported machinery and equipment to the national market;

- insufficient level of technical and servicing maintenance especially of consumers of used imported machinery.

In support of the named problems the Table 1 shows statistics.

Table 1. Manufacture of machinery and equipment for agriculture in Russia

\begin{tabular}{|l|c|c|c|}
\hline Type of machines and equipment & 1993 & 2003 & 2013 \\
\hline Tractors for farmers and forestry, thous. pieces & 106,2 & 4,0 & 5,2 \\
\hline Seeding-machines, thous. pieces & 57,1 & 2,0 & 3,8 \\
\hline Spreader ploughs, thous. pieces & 89,2 & - & 4,7 \\
\hline Mowing machines, thous. pieces & 58,8 & - & 1,8 \\
\hline Combine harvesters, pieces & - & - & 97 \\
\hline Beet harvesters, thous. pieces. & 8,6 & - & - \\
\hline
\end{tabular}

As for use of marketing and logistics approach in the sphere of technical maintenance of agriculture, this direction is studied not enough in Russia. In recent years, the methods of operating business have significantly changed. These changes have led to a new phenomenon, when, along with product quality and price a decisive factor, determining the success of the company's activity, growth in sales of their products, became the ability to sell their products, using the integrated chains of supply from manufacturer to consumer, creating additional value for clients and organizing high quality service (Morozova, 2006).

Peculiarities of marketing and logistics while delivering machinery for the village are associated with the peculiarities of agricultural production as a sphere of application of human labour and getting surplus product. Specific conditions of agricultural production determine the peculiarities of application of marketing and logistics methods while forecasting demand and supply of machinery. These peculiarities are necessary to be systematized according to influence of various factors on agricultural production. Table 2 shows the main peculiarities of agricultural production, which affect forecasting supply and demand of machinery. This classification marks out three groups of peculiarities: natural, economic and organizational. 
Table 2. The main peculiarities of agricultural production, which affect forecasting supply and demand of machinery

\begin{tabular}{|l|l|}
\hline Groups of peculiarities & Contents \\
\hline Natural & $\begin{array}{l}\text { Drastic demand fluctuations as a result of seasonality of manufacture, change of need in machinery in } \\
\text { dependence on crop yield and productivity, short period of using machinery, dependence of the results on } \\
\text { weather conditions, natural and other factors }\end{array}$ \\
\hline Economic & $\begin{array}{l}\text { Low purchasing capacity of the main part of consumers of agricultural machinery, high cost of machinery, } \\
\text { decreasing demand on machines even more, deficit of investments into development of AIC and its } \\
\text { infrastructure, low level of state support of AIC, high logistics costs of delivering machinery to village } \\
\text { commodity producers }\end{array}$ \\
\hline Organizational & $\begin{array}{l}\text { High extent of territorial disconnectedness of manufacture in this connection necessity of production and } \\
\text { organization of a branching service-retail network, close to village commodity producer, long chains of } \\
\text { delivery, low level of organization of marketing, logistics and agro-business in this sphere of activity }\end{array}$ \\
\hline
\end{tabular}

The most important factor, which affects forecasting demand and supply of agricultural machinery, is the natural factor. Its actions largely determine the final results of production and opportunities of purchasing additional equipment by agricultural producers. Natural factor is highly variable, that is why forecasts are variant and subject to ongoing changes. In this regard, delivery conditions get complicated and costs of production and delivery of machinery increase, which also complicates the process of providing agricultural production with material and technical resources.

With specificity of agricultural production, its seasonality most types of agricultural machinery are used during insignificant period of economic year (during the period of sowing, harvesting, etc.). Therefore, demand on certain machines fluctuates sharply: it is maximal during periods of intense work, and in the autumn-winter period reduces to a minimum. And industry produces equipment throughout the year, which raises the problem of linking its supplies with the actual seasonal needs of farms (Carter et al. 2012).

Nowadays marketing environment develops and changes so rapidly that attempts to look at, to describe some static picture, to make a mold of the market leads, rather, to misinformation than determination. In order to determine this sensitivity to changes in time such a definition as "duration of marketing" is introduced. During the recent years, duration of marketing was too big. The market is changing so rapidly that any marketing research is late. It is necessary to invent new methods of marketing research. Right up to such, that simultaneously with introduction of a new product an on-line system of marketing measurement would be created. Thus, market environment develops so rapidly that any marketing research is late. In turn, incorrect marketing forecasting leads to erroneous logistics operations, that is already related with significant financial costs and inefficient trade flows. This statement is especially true for the market of agricultural machinery, as the occurring changes in the market environment are intensified by influence of natural factors which do not depend on will and consciousness of human, complicating forecasting and determination of needs in machinery during the period of intense agricultural works.

The days when demand exceeds supply are already gone. Under the conditions, traditional approaches to management, based on forecasts, stop working. The reason is that the classical statistical forecasting is often based on collection of information about the demand in the past. Then, based on this information models are created, on the basis of which predictions for the future can be made. However, the chaotic nature of demand does not allow building any reliable models, which undermines the basis of 'traditional' method of forecasting. In this regard, it is necessary to reconsider the traditional view of connection between marketing and logistics and to introduce such a term as a marketing logistics (Sheldon, 2007).

Rapid development of information systems, enabling obtaining of real-time data about the current changes in demand, was an also objective prerequisite for emergence of marketing logistics. Obtaining of objective information gives an opportunity to control material flows and to promptly respond to the emerging needs for certain goods.

Thus, taking into account the stated factors, it is possible to formulate the following definition of marketing logistics. Under marketing logistics a systematic approach to management of commodity flows and organization of high-quality service through exchange of information and creation of additional values between participators of chains of supplies to satisfy the changing demand of consumers with operative deliveries should be understood.

The most important place in marketing logistics is given to the skill of establishing, keeping and using personal contact in commercial activity of their companies. Personal contact is a connecting link between employees of different companies. On the basis of personal contact more close relationship between the partners are formed. Personal contact is based on mutual benefit, which is the driving force of similar relationship.

There are many examples when a good personal contact is essential for successful activity of a certain firm in different fields of activity. For example, a head of a consulting firm describes their relationship with other companies: 'I have twenty key customers. I know all about their heads, walk in the same sports clubs with them, know about their 
children's birthdays, and no one but me will not sell them our services'. John D. Rockefeller said that he 'appreciates the ability to communicate with other people and to establish contact as well as any other commodity', and that 'for this skill he is willing to pay more than for any other commodity' (Morozova and Litvinova, 2013). Skill to establish, maintain and use personal contact in commercial activity of their enterprises is, on the one hand, art, and on the other, a science of building relationship with partners, which requires certain skills, principles and methods of work.

In order to maintain personal contact it is necessary to possess information about hobbies, goals, plans and problems of a person useful for you. You should decide which service you can render to help them to achieve the goals and to carry out the plans. As a result, you would have preferences.

All received information about personalities you are interested in is necessary to be analyzed, systematized and used as needed. Thus information database is created and periodically updated with the use of different software. In general, introduction of marketing logistics into activity of dealership enterprises providing agricultural production with technical resources, is an important task of the market of agricultural machinery, the solution of which can significantly improve the level of technical support of the village.

Application of marketing logistics in activity of participants of deliveries of agricultural machinery gives these companies a significant competitive advantage over other companies. These advantages are based on possibility to obtain current information and certain values unavailable for other companies, as well as a number of joint actions in the interests of each link of the supply chain.

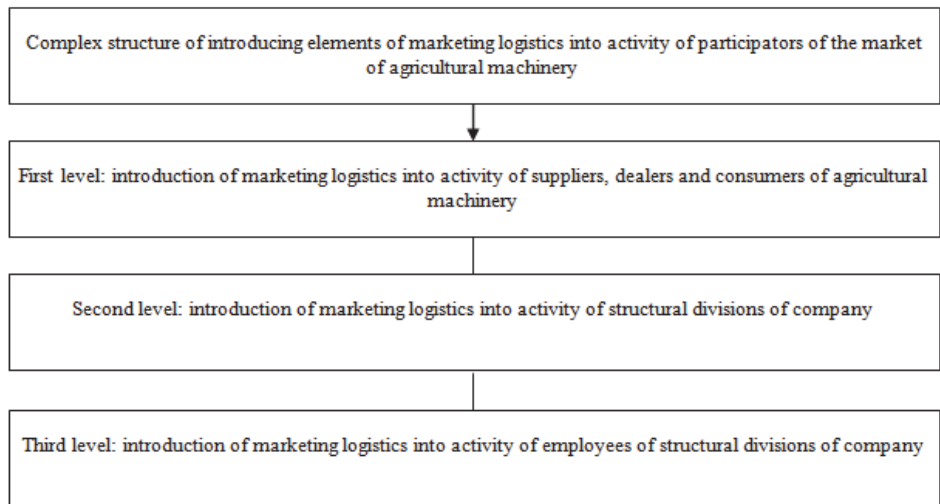

Figure 4. The complex structure of introduction of elements of marketing logistics into activity of participants of the market agricultural machinery

The figure shows three levels elements of marketing logistics within the complex structure of introduction into activity of participants of the market agricultural machinery.

In turn, each level of introduction of marketing logistics involves a number of stages of its conducting. Thus, the first level of introduction of marketing logistics involves the following steps:

1. Stages of introduction of marketing logistics in activity of suppliers, dealers and consumers of agricultural machinery:

- creation of integrated supply chains;

- creation of a unified system of information exchange, joint database and unified form of document circulation;

- creation of a system of values for participants of supply chains;

- $\quad$ establishment of information exchange between members of supply chain;

- operational management of commodity flows on the basis of the received information;

- joint actions to attract new customers;

- joint action to organize servicing;

- joint training and retraining of specialists.

The second level of introduction of marketing logistics involves the following steps:

2. Stages of introduction of marketing logistics into activity of structural divisions of company:

- creation of a single coordinating logistics center;

- creation and introduction of a system of information exchange between structural divisions of company;

- introduction of rational forms of working of structural divisions of company;

- creation and introduction of a system of values for all structural divisions of company. 
The third level of introduction of marketing logistics involves the following steps:

3. Stages of introduction of marketing logistics into activity of employees of structural divisions of company:

- creation and introduction of information exchange system between employees of a structural division of company;

- creation and introduction of a system of values for employees of structural division of company;

- introduction of elements of scientific management of personnel labour of structural division of company.

\section{Discussion}

According to the data of the association 'Rosagromash', in 2014 the total size of the market of the Russian machinery would reach $840 \mathrm{~m}$ doll. (growth only by $7 \%$ ). At the same time, import arrivals of foreign machinery would increase by $20 \%$ and would constitute $1.2 \mathrm{bn}$. doll. The share of Russian-manufactured machines would decrease by $6.6 \%$ and would constitute $36.5 \%$. In other words, displacement of domestic equipment from the Russian market would continue (Xinkai, 2011).

It should be noted that during the years of the crisis production of agricultural machinery in Russia decreased by 2.6 times, while in the EU - only by 7\%, and in the US it remained at the same level. This shows the advantages of foreign mechanism of supporting agricultural machine-building (soft credits for modernization of machinery manufacture, financial support of export of machinery by banks, subsidies for buyers of the countries of the European Union to purchase machines produced by enterprises of this community, and others).

In Russia renewal of technological equipment in factories arise through the limited financial resources of their own, so it does not exceed 1-2\% per year, the average age of machies reaches 16-25 years (5-8 years abroad). Credit rates for modernization of equipment of plants in Russia is 3 times higher and constitute 15\% per annum against 2-6\% abroad. The state does not properly support modernization of equipment, so technological underdevelopment of production accumulates (OECD, 2012).

Our tax system does not encourage investment in machine-building, while the EU supports machines exported from the EU through the banks by loans for 10 years at 4\% per annum (in Russia the same programs assume credit rate of $15 \%$ per annum).

In the EU and the US companies get state support in the form of a $50 \%$ discount when buying machines, full payment by installments, the minimum percentage of payment of the remainder of the loan, etc. It is understandable why agricultural machine-building of the EU and the US suffered minor damage from the crisis. It is necessary to learn the valuable experience of the foreign countries to support agricultural machine-building.

View of some economists about necessity of the state to leave the economy is mistaken. On the contrary, during the crisis the state regulation of the economy should be intensified. It is understood by governments of numerous countries have taken measures to protect the interests of society as a whole. So, even in the end 2008 led by the President of the USA a law prohibiting the participation of firms in the offshore areas (which increased federal revenues by 24 bn doll. per year) was adopted, the secret contributions of the US citizens in a number of foreign banks were revealed. Later uncontrolled activity of large financial monopolies through whose fault the economic crisis began was limited, the question of increase of taxing profitable firms and corporations by eliminating tax benefits previously granted to them by the law is being decided. This fiscal policy in 2008-2010 allowed creating conditions for accelerating the US economy to go out of the crisis at the expense of received additional budget revenues (Xhiwei, et. al., 2013).

This particular industry such as farming, which is influenced by environmental factors, seasonality of production, natural disasters, generally cannot develop without interference and strong support from the side of the state. The proof of this is the high level of expenses of USA and the countries of the European Union of financial support of agricultural production, which are regularly allocated from the budgets of these countries. Similar support is especially needed by farmers and the infrastructure industries in Russia maintaining them.

In this connection Russia's accession to the WTO causes anxiety. Under the terms of the WTO the state would be forced to largely abandon finance support of agricultural engineering (subsidies, protective measures, public procurement, standards, etc.). On the whole nomenclature of equipment customs duties will be reduced up to $5 \%$, which would pave the way to a sharp increase of import of foreign machinery. So, according to experts, in 2020, share of import would constitute of 60 of 65 thousand tractors; as for combine harvesters the market would constitute 9.2 thous., including 8 thous. imported ones; the market of tractor-carried and other equipment would constitute 101 bn rub., including 81.7 bn rub. of imported equipment. (Popkov, Chashchin and Bogdanov, 2013).

This means that the economically developed countries of the WTO, taking the advantage of their superiority in the manufacture of machinery for the village, can fully capture the market of Russia, eliminating domestic machine-building. 
In this case, the country could fall into complete dependence on the importation of basic nomenclature of agricultural machinery that does not correspond with the purposes of achieving food security of the country. That is why it is necessary to radically change the economic policy of the state in the sphere of supporting agricultural machine-building, by providing the necessary financial resources for reconstruction and modernization of the industry and increase of the capacity of the market, in particular by subsidizing costs of manufacturers of agricultural commodity for purchasing most expensive self-propelled machines.

\section{Conclusion}

As a result of the conducted research it can be concluded that there are problems in all aspects of marketing mix in the Russian market of agricultural machinery.

1. Product: rise of the prices for equipment.

2. Price: high level of price competition at high costs of domestic manufacturers.

3. Promotion: rise of competition due to imports.

4. Distribution channels: necessity of searching for new distribution channels because of high non-price competition.

It is possible to highlight the following main trends of development of the Russian market of agricultural machinery:

- in 2013, the market 'dipped' by $2 \%$, by the results of 2013 the decline would constitute $12-13 \%$ in natural terms;

- on the background of the decline in domestic production of agricultural machinery (-5\% in 2012 and $-22 \%$ in 2013) import demonstrates growth (+ 5\% in 2012 and 20\% in 2013);

- the share of domestic production decreased from $86 \%$ in 2010 to $68 \%$ in 2013 ;

- further development of the Russian market of agricultural machinery and equipment will be determined by the measures of the state support of farmers both at the federal and the regional levels. Meanwhile, the current programs to support domestic manufacturers did not bring effect.

Nevertheless, there are prospects of development of the Russian market of agricultural machinery due to modernizing of the economy and state support of domestic manufacturers.

\section{References}

Cai, F., \& Wang, M. (2012). Labour Market Changes, Labour Disputes and Social Cohesion in Chinall, OECD Development Centre Working Paper No. 307, Paris.

Carter, A. et al. (2012). Advances in Chinese Agriculture and its Global Implicationsll, Applied Economic Perspectives and Policy / 34 (1): $15-18$.

Laping, W. (2013). Chinese Grain Supply Demand and Projection: Regional Perspective, manuscript submitted for FAO Technical Cooperation Project TCP / CPR / 3304 -Strengthening of China's Capacity in Agricultural Market Monitoring and Agricultural Outlook.

Laping, W. (2013). How Open is the Chinese Agricultural Sector, manuscript submitted for FAO Technical Cooperation Project TCP I CPR / 3304 -Strengthening of China's Capacity in Agricultural Market Monitoring and Agricultural Outlook.

Morozova, I.A. (2006). Issue of improving competitiveness of Russia's transport system and its integration into international transport system. Izvestiya of VolgGTU (News of Volgograd State Technical University). Series "Current issues of reforming Russian economics (theory, practice, perspective)": Collection of scientific articles. Volgograd State Technical University, 6 (11): 73-77.

Morozova, I.A. and Litvinova T.N. (2013). Major aspects of forecasting entrepreneurial business on the agricultural equipment market. Audit and Financial Analysis. 3 (1): 404-408.

OECD. (2012). China in Focus: Lessons and Challenges, Paris. OECD (2013), Agricultural Policy Monitoring and Evaluation 2013. OECD Countries and Emerging Economies, Paris 2013.

Popkova, E.G., Chashchin, V.V., Bogdanov, D.V. (2013). Implementation of the Concept of Personnel Marketing In Modern Russia. World Applied Sciences Journal. 22 (3): 389-395.

Sheldon I. (2007). China's Agricultural Trade: Issues and Prospects, Papers presented at an IATRC International Symposium, Beijing, 89 July 2007.

Xhiwei, X. Ganqiong, L. \& Jianzhai, W. (2013). Achievements of the agriculture and rural economy in China, manuscript submitted for FAO Technical Cooperation Project TCP / CPR / 3304 -Strengthening of China's Capacity in Agricultural Market Monitoring and Agricultural Outlook.

Xinkai, Z. (2013). China's Current Agricultural Policy Review and Applications of the AglinkCosimo model under Chinese Circumstances, manuscript submitted for FAO Technical Cooperation Project TCP / CPR / 3304 -Strengthening of China's Capacity in Agricultural Market Monitoring and Agricultural Outlook. 